DOI: https://doi.org/10.32839/2304-5809/2021-4-92-70

УДК 331.101.3(045)

Ситник Н.С., Чепіль Ю.Б.

Львівський національний університет імені Івана Франка

\title{
МОТИВАЦІЯ ЯК ЧИННИК СТИМУЛЮВАННЯ ЛЮДЕЙ ДО ЕФЕКТИВНОЇ ДІЯЛЬНОСТІ
}

\begin{abstract}
Анотація. У статті досліджено сутність мотивації праці та її застосування на підприемстві для ефрективної діяльності працівників та економічного зростання підприемства. Охарактеризовано види і методи мотивації та наведено відповідні приклади. Проаналізовано такі поняття, як «мотивація», «стимулювання», виділено їхні спільні та відмінні риси. Зазначено, як мотивація пов'язана зі стимулами до праці, проаналізовано внутрішні та зовнішні чинники впливу на ефективність мотивації. Сформовано принципи побудови системи мотивації праці. Окреслено найедективніші методи мотивації праці і їх індивідуальне визначення для одного або групи працівників. Охарактеризовано моделі мотивації праці зарубіжних держав та на основі такого аналізу запропоновано найоптимальніші варіанти моделей, які підійшли б для реалізації на українському підприемстві.
\end{abstract}

Ключові слова: мотивація працівників, стимулювання, види та методи мотивації, ефективність праці, моделі мотивації.

Sytnyk Nataliia, Chepil Yuliia

Ivan Franko National University of Lviv

\section{MOTIVATION AS A PROCESS OF ENCOURAGING PEOPLE TO EFFECTIVE ACTIVITY}

Summary. The issues of work motivation and its application at the enterprise for effective activity of employees and economic growth of the enterprise are investigated. The types of motivation (external, internal, moral, material, administrative) are highlighted and each of the types is characterized. It was also mentioned that, despite the moral aspects of motivation, in the modern world the most effective motivation for staff work is, after all, material motivation, ie additional wages: surcharges, allowances, bonuses. Motivation methods are indicated, such as economic, socio-psychological, organizational-administrative and examples. The correct individual definition of motivation methods for an employee or a group of employees is considered, taking into account the different interests of workers. That is, for example, for some the priority is the financial component, and for others - the material, so the same motivation for different employees will be completely ineffective. Concepts such as "motivation", "stimulation" are analyzed, their common and distinctive features are highlighted. What is common is the desire to achieve a goal, perform tasks, get a good result, increase innovation, and what is different is that motivation is a more internal desire to work or perform certain tasks, and incentives are external influences on the employee. It is noted how motivation is related to incentives to work, the internal and external factors influencing the effectiveness of motivation are analyzed. The principles that are important to follow when building a system of work motivation are formed. Models of work motivation of different foreign countries, such as Japan, Germany, England and the USA, are characterized. According to this analysis, the best options for models that would be suitable for implementation in the Ukrainian enterprise, namely the American and English models of work motivation in the enterprise. Applying the American model of work motivation allows the company to reduce the cost of manufacturing finished products and expand its volumes, with the help of highly qualified personnel, and the implementation of the English model will increase productivity through their participation in company profits, because they are interested in these profits. the salary of each employee depends on them.

Keywords: employee motivation, incentives, types and methods of motivation, work efficiency, motivation models.

$\Pi^{2}$ остановка проблеми. Для розвитку сучасного суспільства в умовах використання інновацій, важливою складовою $є$ увага до персоналу, тобто його мотивація. Одним iз завдань для підприємства є стимулювання працівників до праці, з метою підвищення його конкурентоспроможності. Ефективна діяльність сучасного підприемства залежить від правильної мотивації робітників. Мотивація є важливою передумовою розвитку як суспільства, так і підприемства в цілому. Кожен працівник, окрім зазначених умов діяльності на підприемстві, має особисті стимули до виконання різних наданих йому завдань. Тому, з допомогою елементів мотивації як видача премій, підвищення заробітної плати, надання можливості зайняти вищу посаду, перекваліфікації, працівники можуть стати більш креативними, удосконалити свою профресійну майстерність та інші практичні навички.
Мотивація впливає і на кінцеві результати діяльності підприемства та гарантуе підвищення економічного зростання, конкурентоспроможність та економічну безпеку.

На наш погляд, ефрективна діяльність працівників створюе можливості щодо впровадження інноваційної діяльності, підвищення рентабельності та конкурентоспроможності на ринку для підприємства і позитивно впливає на його розвиток в цілому.

Аналіз останніх досліджень і публікацій. Аспекти мотивації розглядали у своїх працях як вітчизняні, так і зарубіжні вчені, зокрема: В.М. Абрамов, А.С. Афронін, Д.П. Богиня, Б.М. Данилишин, В.М. Данюк, О.А. Гришова, А.М. Гриненко, Г.Т. Завіновська, Т.А. Заяць, А.В. Калина, А.М. Колот, В.І. Куценко, К. Адельdpep, Ф. Герцберг, А.Г. Здравомислов, Д. МакГрегор, А. МакКлелланд, МакКінсі, А. Маслоу, 
Ю.П. Морозов, У. Оучи, С. Пакулін, О.Є. Рябцев, М.І. Грінько, П.І. Пономаренко, В.В. Бойко, Я. Сухін, П.О. Пономаренко та ін. [1].

Проте, окремі аспекти аналізу чинників ефективної мотиващії персоналу та стимулювання до праці, правильне використання продуктивних якостей працівників завжди буде цікавим фрундаментом до подальших досліджень.

Виділення не вирішених раніше частин загальної проблеми. Вплив мотивації працівників на підвищення інноваційної діяльності, роль методів мотивації і стимулювання, їх значення для ефективного управління підприемством потребують вивчення та розгляду.

Завдання статті полягае у аналізі понять «мотивація», «стимулювання», виділенні їх спільних і відмінних рис, визначенні методів мотивації праці на підприемстві, окресленні ролі мотивації в управлінні підприемством.

Виклад основного матеріалу. Мотивація - це вид управлінської діяльності, який спонукає працівника виконувати свої обов'язки із ентузіазмом, завзятістю, наполегливістю, сумлінністю. Кожне підприемство для ефективного фрункціонування прагне мати конкурентоспроможний персонал, а для цього потрібне вміння так організувати працю, щоб віддача працівників була максимальною. При цому важливим фрактором посилення трудового потенціалу повинна стати особиста зацікавленість працівників, заснована на можливості задоволення їх соціальних і фрізіологічних потреб [2].

Мотивація має багато різних класифікацій, проте, на наш погляд, доцільно виділити такі види мотиващії (рис. 1):

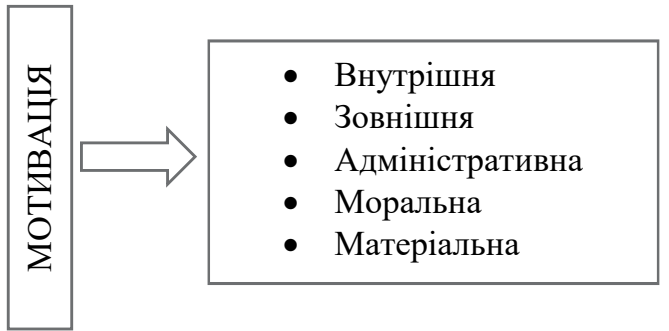

Рис. 1. Види мотивації праці

Джерело: розроблено автором
Зовнішня мотивація насамперед пов'язана 3 матеріальною вигодою, загальними умовами пращі, а внутрішня мотивація працівника залежить від його емоцій і почуттів, які безпосередньо впливають на якість виконання роботи.

Адміністративна мотивація полягає у контролі за виконанням поставлених завдань перед працівником. Наприклад, підприемство мотивує працівників за допомогою матеріальних заохочень, поліпшення умов праці, підвищення у посаді, а робітник неналежно виконуе свої фрункції та завдання, за таких умов до нього застосовуються методи адміністративного впливу (відрахування певної суми коштів із заробітної плати, пониження у посаді чи звільнення).

Що стосуеться моральної мотивації працівників підприемства, то вона грунтуеться на визнанні працівника як окремої особистості. Працівник має відчувати себе комфортно на підприємстві, час від часу чути похвалу від керівництва, що забезпечить морально-сприятливий клімат у колективі. Саме за допомогою таких чинників діє моральна мотивація на працівника.

Ще одним важливим видом мотивації є матеріальна мотивація. Для деяких працівників саме цей вид мотивації $е$ ключовим. Під матеріальною мотивацією розуміють прагнення до достатку, високого матеріального рівня життя. Відомо, що більшість працівників зацікавлені у високій оплаті праці, а для деяких це є головним чинником, який впливає на якість виконання ним посадових обов'язків. Тому оплата праці лежить в основі всіх систем мотивації працівника щодо його продуктивної праці [3].

Отже, мотивація працівника до ефрективної роботи напряму залежить від матеріального аспекту - заробітної плати, премій, винагород, виплат соціального характеру.

Окрім видів мотивації, виділяють і методи мотивації (рис. 2).

Однак, методи мотивації залежать і від індивідуального зацікавлення працівників. Кожна особистість прагне отримати свое, наприклад, дві людини на одній і тій самій посаді можуть мати різні інтереси, мету і вимоги до даного місця працевлаштування. Якщо для працівника

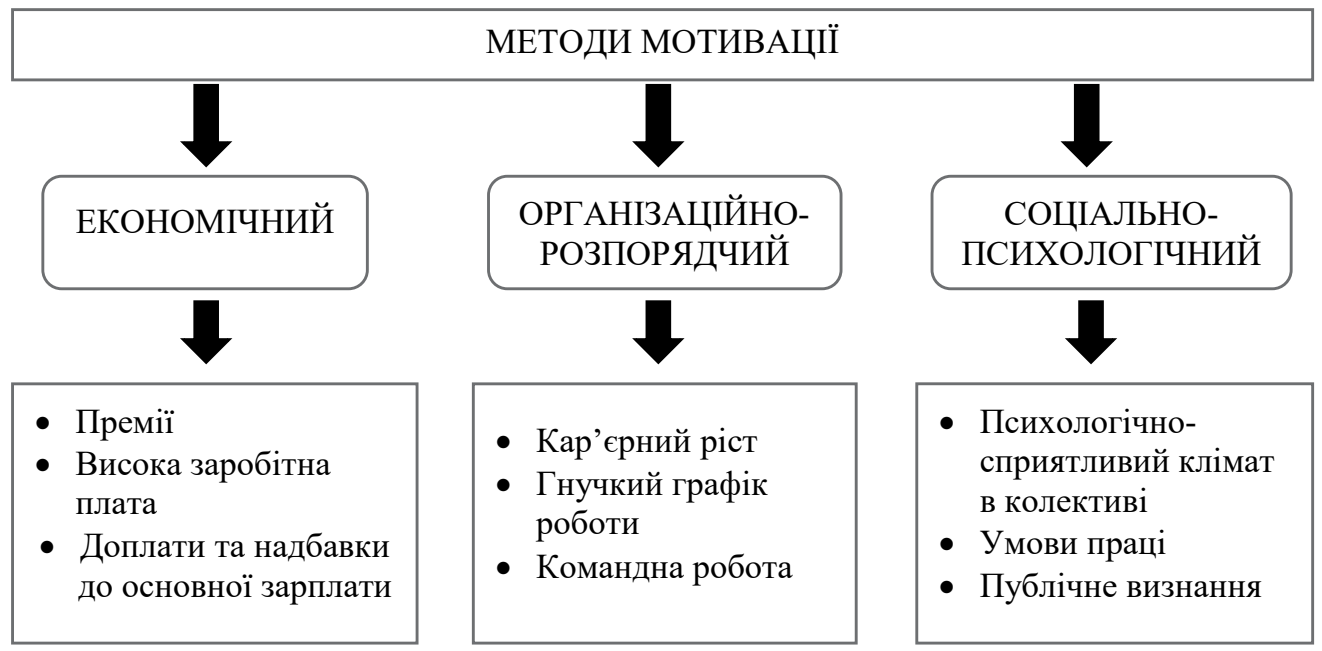

Рис. 2. Методи мотивації праці 
головним бажанням і прагненням на місці роботи є кар'єрний ріст, то його мотивація до едрективної праці полягає у наданні можливості росту по кар'єрній драбині. Для іншого працівника важливим моментом $є$ режим роботи чи питання житла, віддаленої роботи, тоді методи мотивації будуть зовсім іншими.

Найкращими подразниками для досягнення бажаного результату від працівників на підприемстві є стимули, які сприяють підвищенню інтенсивності певних мотивів у діях людини. Стимули бувають соціальні, матеріальні, економічні, творчі, пізнавальні, професійні та ін. Одним із таких видів стимулювання є індивідуалізована винагорода працівникові, яка дозволяе вмотивовувати до виконання завдань та отримувати винагороди у вигляді бонусів та публічного визнання. Отже, суть мотивації працівника до праці проявляеться у стимулах, які впливають на його особисту защікавленість щодо едективного виконання своїх посадових обов'язків.

Так як мотивація праці безпосередньо пов'язана зі стимулами, то умовно можна продемонструвати схему, за якою відбувається сам процес мотивації і отримуеться бажаний результат - «потреби самого працівника або підприемства - інтереси, зацікавленість - стимули до діїуспіх, винагорода».

Незважаючи на це, науковці по різному розглядають поняття «мотивація» та «стимулювання», одні як одне ціле, не виокремлюючи відмін- ності, інші висловлюють думку про абсолютну різницю між цими двома поняттями. Водночас процес стимулювання, під яким зазвичай розуміють вплив на трудову діяльність працівника за рахунок створення індивідуально-значущих умов трудової ситуації, містить у собі зовнішні подразники та структурні компоненти трудової ситуації [4]. Слід зазначити, що стимулювання це своєрідний процес, направлений на конкретну особу персоналу підприемства або їх групу і провокуе чи підштовхує до дії. А мотиващія це теж заохочення до певних дій, але їі метою $€$ виконання поставлених завдань підприємства і отримання відповідного результату. Окрім того, різницею між поняттями «мотивація» і «стимулювання» $є$ те, що за допомогою другого і відбувається саме процес мотивації.

Сьогодні з різних засобів мотиващії праці застосовують тільки її окремі елементи - ця обставина наголошуе на потребі створення цілісної системи мотивації праці персоналу, орієнтованої на розвиток трудового потенціалу працівників та результативність діяльності підприемства загалом [5].

При побудові системи мотивації праці важливо дотримуватися таких принципів (рис. 3):

На ефрективність системи мотивації працівників впливає також ряд чинників (рис. 4).

Створюючи цілісну систему мотивації праці, підприємству необхідно не лише дотримуватись вищезгаданих принципів та чинників ефективності системи, але й зважати на зарубіжний

\begin{tabular}{|c|c|}
\cline { 2 - 2 } & \multicolumn{1}{c|}{ ПРИНЦИПИ ПОБУДОВИ } \\
\cline { 2 - 2 } & \multicolumn{1}{c|}{ СИСТЕМИ МОТИВАЦІЇ ПРАЦІ } \\
$\checkmark$ & типовість і прогресивність відібраних інтересів; \\
$\checkmark$ & присутність у кожному стимулі особистого інтересу; \\
$\checkmark$ & присутність в одному стимулі кількох протилежних інтересів; \\
$\checkmark$ & верховенство одних стимулів над іншими; \\
$\checkmark$ & простота і наочність системи
\end{tabular}

Рис. 3. Принципи побудови системи мотивації праці

Джерело: розроблено автором на основі [6]

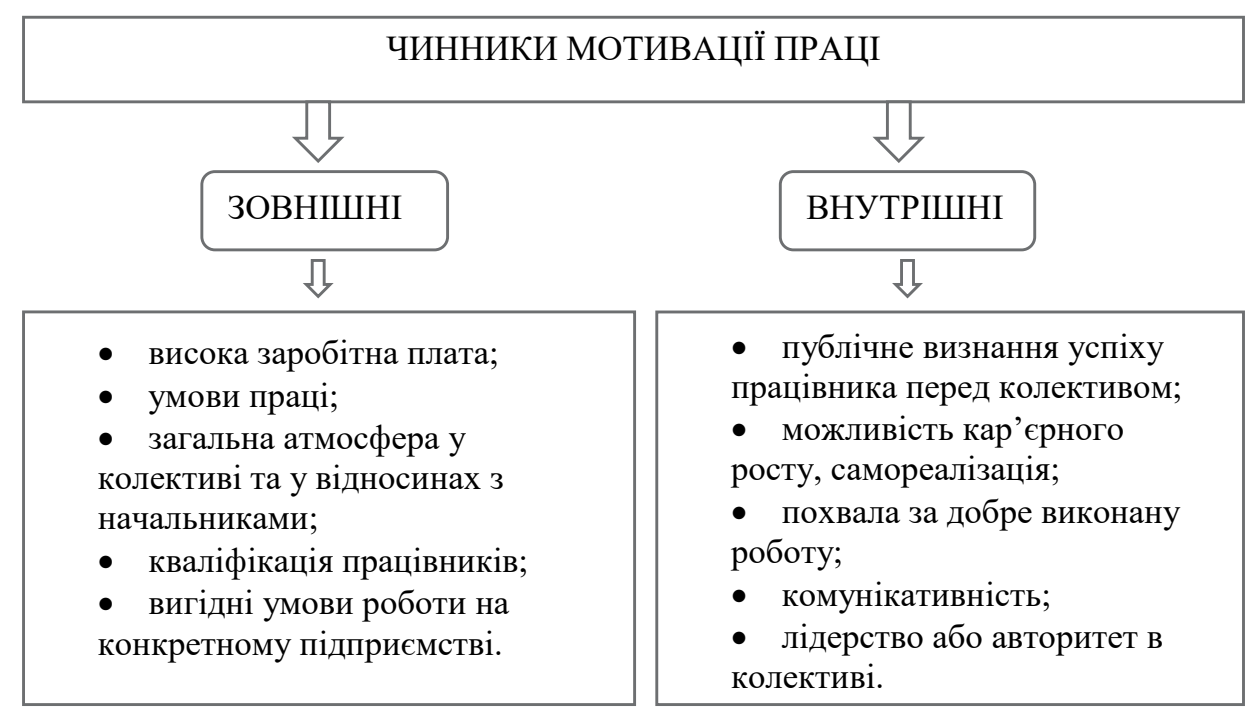

Рис. 4. Чинники мотивації праці 
досвід високорозвинених країн. Тому, на нашу думку, є доцільним розглянути моделі мотивації праці в окремих зарубіжних країнах.

Так, японська модель мотиващії є досить гнучкою та побудована на трьох основних елементах: продресійна майстерність працівника, вік та стаж. Тобто, оклад нараховуеться у вигляді суми виплат за стаж, за результативність праці, за кваліфрікаційний розряд та вік. Отже, підвищення заробітної плати згідно японської моделі мотивації є можливим лише за умов підвищення кваліфрікації та продуктивності праці працівників. Окрім цього, японській моделі притаманний принцип пожиттевого найму працівників, який має на меті перекваліфікацію та ротацію кадрів. Згідно таких умов, працівники зацікавлені працювати на перспективу, адже їх досягнення на підприємстві сьогодні, впливатимуть на їх матеріальне забезпечення у майбутньому.

Щодо американської моделі мотивації праці, то їй притаманне певне заохочення працівників до підприємницької активності. До уваги беруть досягнення успіху кожного робітника зокрема. В основі цієї моделі немає преміювання, доплат чи надбавок, адже вони вже закладені у досить високих тарифнних ставках. Підприємство, нараховуючи заробітну плату, опираеться на квалірікацію працівників. Наприклад, робітник отримує бали за перекваліфікацію і на їх основі йому передбачається підвищення заробітної плати.

Американській моделі притаманні різні методи мотивації праці, але насамперед той, який пов'язаний із матеріальним заохоченням. В якості прикладу можна представити досвід американських фpipм «Ford» та «General Motors», де часто застосовуються "гнучкі системи» оплати праці працівникам з використанням аналітичної оцінки робочих місць щодо важкості і складності роботи, яку вони виконують. При цьому змінна частина заробітної плати, яка виступає в якості нагороди за підвищення якості продукції, зростання продуктивності праці, економія сировини досягає 1/3 зарплати [7].

Англійська модель мотивації пращі базуеться на двох формах виплати заробітку працівникам - акціонерній і грошовій. Остання є зрозумілою, однак акціонерну форму слід розглянути детальніше. За такої моделі, робітник має можливість вкладати свої фрінансові ресурси в цінні папери і кожного місяця отримувати від вкладень відсотки. Таким чином, працівники, котрі зацікавленні у отриманні більшої заробітної плати, працюють ефрективніше i, як результат, прибутки підприемства теж зростають.

Німецькій моделі мотивації праці притаманні справедливість та солідарність і створюються рівні умови для всіх громадян, засуджуеться несправедливість і надаеться захист безробітним, людям похилого віку, хворим тощо. За такої моделі підприемство поєднує стимули до праці із соціаль- ними гарантіями. Західні дослідники вважають німецьку модель мотивації праці найкращою із всіх відомих, бо застосовуючи ії забезпечуеться як економічний добробут, так і соціальні гарантії.

На нашу думку, впровадження будь-якої iз вищезазначених моделей мотивації праці в Україні повинно залежати від ряду чинників: фінансових можливостей підприємства, менталітету робітників, а також сприятливої економічної ситуації в країні. 3 огляду на вищезазначене, можна виділити окремі елементи моделей, які б підійшли для реалізації на українському підприемстві. Найбільш підхожими для нас є англійська та американська моделі. Так, англійська модель передбачає заохочення працівників до продуктивної праці на основі їх участі у при-

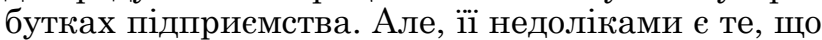
по-перше не кожний робітник буде мати змогу вкласти свої фрінансові ресурси у цінні папери, а по-друге важко вирахувати особистий вклад робітника у загальний результат.

Застосування американської моделі мотивації праці дозволяє підприємству зменшити витрати на виготовлення готової продукцї та збільшити ії обсяги, використовуючи висококваліфікований персонал. Проте, така модель може стати не під силу багатьом українським підприємствам, адже в ії основі лежить перекваліфікація та атестація робітників.

Щодо німецької чи японської моделей мотивації праці, то їх впровадження в Україні $є$ досить складним, адже наші підприемства не $є$ достатньо підготовленими для соціальних гарантій або довічного найму працівників та й не кожен українець зможе працювати на одному робочому місці впродовж життя, з огляду на відмінності в менталітеті.

Висновки 3 даного дослідження і пропозиції. Отже, роль мотивації праці на підприемстві є значною. Без мотивації працівників, підприємство не зможе повноцінно фрункціонувати, отримувати бажані результати та бути задоволеним ïx роботою. Тому, мотивація є важливою складовою в управлінні підприємством і їі необхідно розвивати та вдосконалювати. Недосконалість мотиващії гальмуе розвиток як підприемства, так і його працівників. Саме мотивація та спонукання персоналу до ефективної праці є одним i3 чинників, які створюють можливості підприемству бути конкурентоспроможним, отримувати стабільний прибуток, економно використовувати матеріальні ресурси, а працівникам - реалізувати себе як висококваліфікований фрахівець та отримувати стабільний дохід. Отже, управління персоналом підприемства є неможливим без запровадження мотивації праці, бо недосконала система мотиващії не буде сприяти економічному розвитку підприемства, а навпаки - гальмувати його. Тобто, можна стверджувати, що мотиващія відіграє безумовно велику роль в ефрективному управлінні підприемством.

\section{Список літератури:}

1. Пономаренко О.П. Визначення рейтингу чинників мотивації праці за допомогою модифікованої матриці. Механізм регулювання еконоліки. 2007. № 1(29). С. 171-181.

2. Бала В.В., Мацак А.Г. Теоретичні засади формування системи мотивації персоналу на основі аналізу мотиваційних теорій. Еконолічний фборул. 2014. № 3. С. 136-144.

3. Газгиреева Л.Х. Мотивация как әкзистенциальная потенция духовно-нравственного бытия. Социальноэкономические знания. 2010. № 5. С. 219-227. 
4. Біліченко О.С. Класичні і сучасні моделі мотивації трудової діяльності. Вісник аграрноїнауки Причорнолор'я. 2012. № 4. C. 119-125.

5. Васюта В.Б., Бульбаха Л.І. Мотивація праці персоналу на підприемстві в сучасних умовах господарювання. Eфбективна еконоліка. 2016. № 6. URL: http://www.economy.nayka.com.ua

6. Гуторов О.I., Абраменко П.О. Сучасні теорії мотивації й особливості їх застосування в умовах ринкового середовища. Вісник Харківського національного аграрного університету іл. В.В. Докучаєва. Сер. : Економічні науки. 2013. № 8. C. 10-17. URL: http://nbuv.gov.ua/j-pdf/Vkhnau_ekon_2013_8_4.pdf

7. Гольда А.В. Зарубіжний досвід мотивації праці трудового потенціалу в умовах ринкової економіки. Формування ринкових відносин в Україні : Збірник наук. праць. Вип. 2(33) / Наук. ред. І.К. Бондар. Київ, 2008. C. 94-97.

\section{References:}

1. Ponomarenko O.P. (2007) Vyznachennia reitynhu chynnykiv motyvatsii pratsi za dopomohoiu modyfikovanoi matrytsi [The mechanism of economic regulation]. Mekhanizm rehuliuvannia ekonomiky, vol. 29, no. 1, pp. 171-181.

2. Bala V.V., Matsak A.H. (2014) Teoretychni zasady formuvannia systemy motyvatsii personalu na osnovi analizu motyvatsiinykh teorii [Theoretical bases of formation of system of motivation of the personnel on the basis of the analysis of motivational theories]. Ekonomichnyi forum, no. 3, pp. 136-144.

3. Hazghyreeva L.Kh. (2010) Motyvatsyia kak ekzystentsyalnaia potentsyia dukhovno-nravstvennoho bytiya [Motivation as the existential potential of spiritual and moral being]. Sotsialno-ekonomycheskye znanyia, no. 5, pp. 219-227.

4. Bilichenko O.S. (2012) Klasychni i suchasni modeli motyvatsii trudovoi diialnosti [Classical and modern models of work motivation]. Visnyk ahrarnoi nauky Prychornomor’ia, no. 4, pp. 119-125.

5. Vasiuta V.B., Bulbakha L.I. (2016) Motyvatsiia pratsi personalu na pidpryiemstvi $\mathrm{v}$ suchasnykh umovakh hospodariuvannia [Motivation of staff at the enterprise in modern business conditions]. Efektyvna ekonomika [Efficient economy] (electronic journal), no. 6. Available at: http://www.economy.nayka.com.ua (accessed 29 April 2021).

6. Hutorov O.I., Abramenko P.O. (2013) Suchasni teorii motyvatsii y osoblyvosti yikh zastosuvannia v umovakh rynkovoho seredovyshcha [Modern theories of motivation and features of their application in a market environment]. Visnyk Kharkivskoho natsionalnoho ahrarnoho universytetu im. V.V. Dokuchaieva (electronic journal), no. 8, pp. 10-17. Available at: http://nbuv.gov.ua/j-pdf/Vkhnau_ekon_2013_8_4.pdf (accessed 29 April 2021).

7. Holda A.V. (2008) Zarubizhnyi dosvid motyvatsii pratsi trudovoho potentsialu v umovakh rynkovoi ekonomiky [Foreign experience of labor motivation of labor potential in a market economy]. Formuvannia rynkovykh vidnosyn v Ukraini: Zbirnyk nauk. prats [Formation of market relations in Ukraine: Collection of Sciences. wash.] (eds. I.K. Bondar), vol. 2 , no. 33, pp. 94-97. 